\title{
MENYOAL PENAFSIRAN TANAH TELANTAR
}

\author{
Kajian Putusan Nomor 24/G/2013/PTUN.JKT
}

\section{A QUESTION OF INTERPRETATION ABOUT DERELICT LAND}

\author{
An Analysis of Court Decision Number 24/G/2013/PTUN.JKT
}

\author{
Dian Aries Mujiburohman \\ Sekolah Tinggi Pertanahan Nasional \\ Jl. Tata Bumi No. 5 Banyuranden Gamping Sleman, Yogyakarta 55293 \\ E-mail: esamujiburohman@yahoo.com
}

Naskah diterima: 27 Juni 2017; revisi: 22 Maret 2018; disetujui 27 Maret 2018

http://dx.doi.org/10.29123/jy.v11i1.168

\begin{abstract}
ABSTRAK
Putusan Nomor 24/G/2013/PTUN.JKT merupakan putusan mengenai pembatalan keputusan penetapan tanah telantar yang berasal dari Hak Guna Usaha (HGU) atas nama PT SMG. Pokok sengketa yang menjadi perdebatan dan tafsir dalam gugatannya adalah pengertian tanah telantar dan mengenai surat peringatan sebagaimana diatur dalam Pasal 8 Peraturan Pemerintah Nomor 11 Tahun 2010 tentang Penertiban dan Pendayagunaan Tanah Telantar serta implikasi pasca pembatalan surat keputusan penetapan tanah telantar oleh pengadilan tata usaha negara. Rumusan masalah dalam penelitian ini adalah bagaimanakah penafsiran pengertian tanah telantar dan penafsiran mengenai surat peringatan dalam Putusan Nomor 24/G/2013/PTUN. JKT, serta apa implikasi pembatalan surat keputusan penetapan tanah telantar pasca Putusan Nomor 24/G/2013/PTUN.JKT? Melalui metode penelitian hukum normatif dengan pendekatan studi kasus dapat disimpulkan bahwa adanya perbedaan penafsiran mengenai pengertian tanah telantar terkait dengan frase "dengan sengaja" dan "tidak sengaja," majelis hakim berpendapat bahwa hambatan pemanfaatan tanah karena menunggu proses permohonan pelepasan kawasan hutan dan permasalahan tata ruang serta kendala terhadap
\end{abstract}

pembebasan lahan dan proses ganti rugi disimpulkan sebagai unsur ketidaksengajaan. Implikasi pembatalan surat keputusan penetapan tanah telantar adalah tidak dapat didayagunakan untuk kepentingan masyarakat dan negara.

Kata kunci: surat keputusan penetapan, tanah telantar, putusan pengadilan.

\section{ABSTRACT}

Decision of State Administrative Court Number 24/G/2013/PTUN.JKT constitutes a ruling of the revocation of a derelict land settlement agreement derived from Cultivation Rights on behalf of SMG Company. The subject of the dispute debated in the interpretation of the lawsuit is the definition of derelict land and warning letters, as regulated in Article 8 of Government Regulation Number 11 of 2010 regarding Policies and Utilization of Derelict Land and the implications of post-revocation of derelict land stipulated decree by the Administrative Court. The formulation of the problem in this research is the interpretation of derelict land definition and warning letters in the Administrative Court Decision Number 24/G/2013/PTUN.JKT, as well as the implication of revocation of derelict land settlement 
agreement after the court decision issuance. Through normative legal research method with case study approach, it can be underlined that there is difference in interpretation of the definition of derelict land related to the phrase "intentionally" and "unintentionally", in which the judges argue that barriers to land utility are the still-in-process request of forest areas acquisition,

\section{PENDAHULUAN}

\section{A. Latar Belakang}

Era pemerintahan sekarang, Jokowi-JK mencanangkan program percepatan pelaksanaan program strategis nasional reforma agraria. Kebijakan ini berdasar pada Rencana Kerja Pemerintah (RKP) tahun 2017 yang di dalamnya menempatkan reforma agraria sebagai prioritas nasional yang mencakup program prioritas antara lain penguatan kerangka regulasi dan penyelesaian konflik agraria; penataan penguasaan dan pemilikan Tanah Objek Reforma Agraria (TORA); kepastian hukum dan legalisasi atas TORA; pemberdayaan masyarakat dalam penggunaan, pemanfaatan, dan produksi atas TORA; serta kelembagaan pelaksana reforma agraria di pusat dan daerah (Kantor Staf Kepresidenan, 2016: 1).

Sesuai dengan salah satu sembilan agenda prioritas Nawa Cita pemerintahan Jokowi-JK, yaitu: "mendorong land reform dan program kepemilikan tanah seluas 9 juta hektar" sebagaimana termuat dalam dokumen Rencana Pembangunan Jangka Menengah Nasional (RPJMN) 2015-2019. Program tersebut bertujuan agar setiap warga negara mempunyai kesempatan untuk memiliki tanah, sebagai tempat menetap atau sebagai tempat memperoleh sumber penghidupan secara layak. Dalam hal ini, Kementerian Agraria dan Tata Ruang/ spatial problems and constraints to land acquisition, as well as the compensation process concluded as an element of inadvertence. The revocation of the settlement agreement makes it impossible to use the derelict land for benefit of the people and the state.

Keywords: determination decree, derelict land, court decision.
Badan Pertanahan Nasional (Kementerian ATR/ BPN) menjabarkan tanah untuk reforma agraria berjumlah 9 juta hektar terbagi menjadi dua, yaitu legalisasi aset dan redistribusi tanah yang masing-masing 4,5 juta hektar.

Redistribusi tanah 4,5 juta hektar yang di antaranya adalah Hak Guna Usaha (HGU) yang telah habis, serta dari tanah-tanah yang ditelantarkan yang berjumlah 0,4 juta hektar dilakukan dengan cara penertiban tanah-tanah yang ditelantarkan yang telah dilakukan sejak tahun 1998 dengan diterbitkannya Peraturan Pemerintah Nomor 36 Tahun 1998 tentang Penertiban dan Pendayagunaan Tanah Telantar, kemudian diganti dengan Peraturan Pemerintah Nomor 11 Tahun 2010.

Berdasarkan data penetapan tanah telantar oleh Direktorat Jenderal Penertiban dan Pendayagunaan Tanah Telantar Kementerian ATR/BPN, pada tahun 2017 tanah terindikasi telantar seluas 4.880.598,3049 hektar. Dari luasan tersebut dikeluarkan dari database tanah terindikasi telantar seluas 465.062,3227 hektar, yang diusulkan penetapan tanah telantar dengan luasan 1.081.160,5358 hektar, yang belum dilakukan penertiban seluas 3.334.375,4464 hektar. Dari luas tanah terindikasi telantar seluas 4.880.598,3049 hektar, yang ditetapkan sebagai tanah telantar seluas 75.475,1493 hektar, kemudian yang belum ditetapkan sebagai tanah 
telantar seluas 1.005.685,3865 hektar. Tanah yang diperkarakan di pengadilan tata usaha negara seluas 51.679,7038 hektar. Jumlah subjek hak 3.066 pemegang hak atas tanah/DPAT. Berikut adalah data tanah terindikasi telantar pada tahun 2017.
PT SMG selaku pengugat merasa tidak pernah menelantarkan $\mathrm{HGU}$ dan telah melaksanakan segala kewajiban yang diatur dalam ketentuan Pasal 103 ayat (1) Peraturan Menteri Negara Agraria/Kepala Badan Pertanahan Nasional Nomor 9 Tahun 1999

Tabel 1. Data Tanah Terindikasi Telantar Tahun 2017

\begin{tabular}{clr}
\hline No. & \multicolumn{1}{c}{ Jenis Hak/DPAT } & \multicolumn{2}{c}{ Luas Terindikasi Telantar (Ha) } \\
\hline 1. & Hak Guna Usaha & $1.034 .090,4361$ \\
\hline 2. & Hak Guna Bangunan & $57.713,7789$ \\
\hline 3. & Hak Pakai & $5.612,3920$ \\
\hline 4. & Hak Pengelolaan & $204.510,7950$ \\
\hline 5. & Izin Lokasi & $3.578 .670,9029$ \\
\hline & Jumlah & $\mathbf{4 . 8 8 0 . 5 9 8 , 3 0 4 9}$ \\
\hline
\end{tabular}

Sumber: Direktorat Jenderal Penertiban dan Pendayagunaan Tanah Telantar Kementerian ATR/BPN

Tataran praktik dalam menertibkan tanah-tanah yang ditelantarkan yang luasannya jutaan hektar dengan kerugian negara triliunan rupiah bukanlah perkara mudah. Banyak kasus penetapan tanah telantar dijadikan objek gugatan di pengadilan tata usaha negara menghadapi perlawanan dari pemegang hak/ perusahaan yang mempunyai pengaruh dalam pelaksanaan kebijakan dan tidak didukung oleh instansi sektoral, sehingga di dalam putusannya didominasi dengan pembatalan dan pencabutan surat keputusan penetapan tanah telantar.

Salah satu penetapan tanah telantar yang digugat di pengadilan tata usaha negara adalah Keputusan Nomor 1 dan 2/PTT-HGU/BPN RI/2013 tentang Penetapan Tanah Telantar yang berasal dari HGU Nomor 44 dan Nomor 43 atas nama PT SMG yang bergerak di bidang perkebunan kelapa sawit dan memiliki lokasi usaha di Provinsi Kalimantan Tengah seluas $\pm 17.667,49$ hektar. tentang Tata Cara Pemberian dan Pembatalan Hak Atas Tanah Negara dan Hak Pengelolaan, yakni dengan mengoptimalkan penggunaan tanah untuk perkebunan sawit, mengamankan areal HGU dan memelihara tanda-tanda batas, mencegah kerusakan-kerusakan dan hilangnya kesuburan tanah serta menggunakan tanah sesuai kondisi lingkungan hidup.

Keputusan-keputusan tergugat mengakibatkan terjadinya tumpang tindih kebijakan antar badan/pejabat pemerintah yang justru menghambat rencana dan upaya-upaya untuk mengusahakan dan memanfaatkan kedua areal HGU secara maksimal. Di samping itu areal HGU sedang dalam proses pelepasan kawasan hutan sehingga belum dapat dilakukan pembukaan lahan. Oleh karenanya tidak dapat dikatakan menelantarkan areal HGU dimaksud.

$$
\text { Majelis hakim dalam putusannya }
$$
menyatakan bahwa: 
1. Tergugat melaksanakan pemeriksaan lapangan tidak secara memadai dan sebagaimana mestinya di areal HGU Nomor 43 dan Nomor 44 karena yang bersangkutan tidak masuk di areal tersebut sebagaimana dalam ketentuan Pasal 7 huruf d Peraturan Pemerintah Nomor 11 Tahun 2010 yang menyatakan bahwa identifikasi dan penelitian harus melaksanakan pemeriksaan fisik di lapangan;

2. Sesuai keterangan ahli yang bernama Arie Sukanti Hutagalung menerangkan apabila di areal tersebut ditentukan sebagai kawasan hutan maka harus mendapatkan izin pelepasan hutan dari instansi terkait karena sebelum HGU dikeluarkan oleh Badan Pertanahan Nasional tentunya mempertimbangkan hasil penelitian panitia yang menyatakan bahwa sudah sesuai dengan RTRWP maka dikeluarkanlah HGU sehingga apakah tanah tersebut bisa dinyatakan tanah telantar atau tidak;

3. Sesuai fakta hukum tersebut, keputusan keduaobjeksengketayang diterbitkannyatanyata telah merugikan dan membebani penggugat selaku pemegang hak karena tergugat tidak memperhatikan kepentingan penggugat dalam pembangunan perkebunan dengan mengabaikan fakta-fakta realisasi pembangunan kebun dan tergugat tidak mempertimbangkan kesesuaian tata ruang dengan areal kedua HGU dari semula berstatus Kawasan Pengembangan Produksi (KPP) menjadi Hutan Produksi Konversi (HPK), dan perubahan status tersebut telah disampaikan kepada tergugat sesuai keterangan saksi dari kehutanan, sehingga penggugat harus terlebih dahulu memproses izin pelepasan kawasan hutan kepada Menteri Kehutanan.

Berdasarkan permasalahan tersebut di atas, penulis tertarik mengkaji Putusan Nomor 24/G/2013/PTUN.JKT atas nama PT SMG yang HGU-nya telah ditetapkan sebagai tanah telantar. Pada umumnya keputusan penetapan tanah telantar sebagai objek sengketa di pengadilan tata usaha negara dalam pokok sengketa yang menjadi perdebatan dan tafsir dalam gugatannya adalah pengertian tanah telantar dan mengenai surat peringatan sebagaimana diatur dalam Pasal 8 Peraturan Pemerintah Nomor 11 Tahun 2010. Sehingga pengadilan tata usaha negara menganggap terdapat tahapan-tahapan yang tidak dipatuhi, sehingga mayoritas mengandung suatu kesalahan/cacat hukum baik dari segi kewenangan, prosedur serta substansinya.

\section{B. Rumusan Masalah}

Berdasarkan latar belakang di atas, maka rumusan masalah yang akan dikaji sebagai berikut:

1. Bagaimanakah penafsiran pengertian tanah telantar dan penafsiran mengenai surat peringatan dalam Putusan Nomor 24/G/2013/PTUN.JKT?

2. Apa implikasi pembatalan surat keputusan penetapan tanah telantar pasca Putusan Nomor 24/G/2013/PTUN.JKT?

\section{Tujuan dan Kegunaan}

Adapun tujuan dari penulisan ini adalah sebagai berikut:

1. Untuk menganalisis penafsiran tanah telantar dan penafsiran mengenai surat peringatan dalam Putusan Nomor 24/G/2013/PTUN.JKT. 
2. Untuk menjelaskan implikasi pembatalan surat keputusan penetapan tanah telantar pasca Putusan Nomor 24/G/2013/PTUN. JKT.

Kegunaan yang diharapkan dalam penulisan ini adalah dapat memberikan sumbangan pengetahuan khususnya mengenai penafsiran tanah telantar dalam penertiban tanah-tanah telantar yang mempunyai dampak tanah telantar tidak dapat didayagunakan untuk kepentingan masyarakat dan negara.

\section{Tinjauan Pustaka}

\section{Hak Menguasai Negara Atas Tanah}

Permasalahan agraria (khususnya tanah) adalah soal hidup dan penghidupan manusia, karena tanah adalah asal dan sumber makanan bagi manusia. Perebutan tanah berarti perebutan makanan, perebutan tiang hidup manusia. Untuk ini, orang rela menumpahkan darah, mengorbankan segala yang ada demi mempertahankan hidup selanjutnya (Tauhiid, 2009: 1). Tanah sebagai masalah penghidupan masyarakat, erat hubungannya dengan soal-soal politik, ekonomi, budaya, sosial, pertahanan keamanan, aspek hukum, dan hak asasi manusia, karena tanah bukan saja menyangkut hubungan fisik. Penjelasannya pun tidak cukup hanya ditinjau dari satu segi saja.

Tanah mempunyai sifat unik karena persediaannya selalu tetap, artinya tanah tidak dapat diproduksi maupun dikurangi dan lokasinya tidak dapat digeser atau dipindahkan. Maka permasalahan apapun yang muncul terkait pertanahan akan berimplikasi dengan seluruh aspek kehidupan yang saling berkaitan, karena tanah bagi masyarakat memiliki makna multidimensional. Dari sisi ekonomi, tanah merupakan sarana produksi untuk menghasilkan barang yang dapat mendatangkan kesejahteraan.

Secara politis tanah dapat menentukan posisi seseorang dalam pengambilan keputusan masyarakat dan sebagai budaya yang dapat menentukan tinggi rendahnya status sosial pemiliknya.

Menurut Ismail (2012: 33-51), memiliki tanah terkait dengan harga diri (nilai sosial), sumber pendapatan (nilai ekonomi), kekuasaan dan hak previlise (nilai politik), dan tempat untuk memuja Sang Pencipta (nilai sakral-budaya). Tidak mempunyai tanah berarti kehilangan harga diri, sumber hidup, kekuasaan, dan tempat penghubung antara manusia dengan Sang Pencipta. Kebutuhan memiliki tanah merupakan keniscayaan.

Tanah yang selama ini menjadi sumber kehidupan sebagian besar masyarakat Indonesia. Faktor penyebabnya antara lain:

a. Kelangkaan tanah yaitu terbatasnya luas tanah yang relatif statis dihadapkan dengan kebutuhan tanah karena semakin bertambahnya penduduk.

b. Terdapat proses kehilangan tanah, karena untuk kebutuhan industri baik untuk pabrik maupun perumahan hingga mengurangi lahan pertanian.

c. Proses fragmentasi tanah baik karena pengalihan hak secara jual beli atau pewarisan.

d. Membengkaknya pengangguran di bidang pertanian menyebabkan posisi tawar penggarap terhadap pemilik tanah semakin melemah.

e. Konsentrasi tanah pada beberapa orang 
yang luasnya ratusan hektar, yang akhirnya tidak diusahakan sesuai dengan tujuan perolehannya, menyebabkan banyak tanah telantar (Sodiki, 2013: 156).

Di sisi lain tanah tidak bertambah luasnya memyebabkan tekanan terhadap tanah semakin berat, jumlah penduduk yang terus bertambah, kebutuhan akan tanah untuk perumahan, prasarana dan industri telah mendesak tanahtanah pertanian dan hutan. Perubahan-perubahan ini menjadi salah satu masalah utama yang dihadapi bangsa Indonesia.

Kedudukan dan fungsi tanah begitu sangat penting bagi kehidupan manusia, maka diatur dalam konstitusi tertinggi yaitu Pasal 33 ayat (3) UUD NRI 1945 yang berbunyi: "Bumi, air dan kekayaan alam yang terkandung di dalamnya dikuasai oleh negara dan dipergunakan untuk sebesar-besarnya kemakmuran rakyat," pasal ini menunjukkan hubungan negara dan rakyat dalam penguasaan tanah dan kekayaan alam.

Hak penguasaan dalam Pasal 33 ayat (3) UUD NRI 1945 dijabarkan ke dalam UndangUndang Nomor 5 Tahun 1960 tentang Peraturan Dasar Pokok-Pokok Agraria. Penjabaran ketentuan hak penguasaan negara tertuang dalam Pasal 1 Undang-Undang Nomor 5 Tahun 1960. Bahwa bumi air dan ruang angkasa, termasuk kekayaan alam yang terkandung di dalamnya itu pada tingkatan tertinggi dikuasai oleh negara.

Pasal 2 ayat (2) mengelaborasi konsep hak mengusai negara. Makna "dikuasai” dalam pasal ini bukanlah berarti "dimiliki," akan tetapi adalah pengertian, yang memberi wewenang kepada negara, sebagai organisasi kekuasaan dari Bangsa Indonesia itu, untuk pada tingkatan yang tertinggi untuk mengatur dan menyelenggarakan peruntukan, penggunaan, persediaan dan pemeliharaannya; menentukan dan mengatur hak-hak yang dapat dipunyai atas (bagian dari) bumi, air dan ruang angkasa itu; menentukan dan mengatur hubungan-hubungan hukum antara orang-orang dan perbuatan-perbuatan hukum yang mengenai bumi, air, dan ruang angkasa.

Tujuan dari hak mengusai negara dijelaskan di dalam ketentuan Pasal 2 ayat (3) sebagai berikut:

Wewenang yang bersumber pada hak menguasai dari negara tersebut pada ayat (2) pasal ini digunakan untuk mencapai sebesar-besar kemakmuran rakyat dalam arti kebangsaan, kesejahteraan dan kemerdekaan dalam masyarakat dan negara hukum Indonesia yang merdeka, berdaulat, adil, dan makmur.

Berdasarkan wewenang tersebut, negara berkewajiban untuk:

a. Membuat rencana umum mengenai persediaan, peruntukan dan pengunaan bumi, air dan ruang angkasa serta kekayaan alam yang terkandung di dalamnya untuk keperluan politis, ekonomis dan sosial;

b. Menentukan adanya hak atas permukaan bumi;

c. Berusaha agar sebanyak mungkin orang mempunyai hubungan dengan tanah, dengan menentukan luas maksimum tanah yang boleh dimiliki/dikuasai;

d. Menentukan bahwa setiap orang atau badan hukum yang mempunyai suatu hak atas tanah, mengusahakan tanah itu sendiri, dengan beberapa pengecualian;

e. Berusaha agar tidak ada tanah telantar;

f. Mengatur hubungan-hubungan hukum antara orang-orang dan perbuatan- 
perbuatan hukum mengenai bumi, air ruang angkasa;

g. Mengatur pembukaan tanah, pemungutan hasil hutan dan penggunaan air dan ruang angkasa;

h. Mengatur pengembalian kekayaan alam yang terkandung di bumi, air, dan ruang angkasa;

i. Mengadakan pendaftaran tanah di seluruh wilayah Indonesia untuk menjamin kepastian hukum (Soetiknjo, 1983: 51-52).

Atas dasar hak menguasai dari negara ditentukan adanya macam-macam hak atas tanah, yang dapat diberikan kepada dan dipunyai oleh orang-orang baik sendiri maupun bersama-sama dengan orang lain serta badan-badan hukum (Pasal 4 Undang-Undang Nomor 5 Tahun 1960).

Hak tanah merupakan hak penguasaan atas tanah yang berisikan serangkaian wewenang, kewajiban dan/atau larangan bagi pemegang haknya untuk "berbuat sesuatu" mengenai tanah yang dihaki. "Sesuatu" yang boleh, wajib atau dilarang untuk diperbuat, yang merupakan isi hak penguasaan itulah yang menjadi kriteria atau tolak pembeda di antara hak-hak penguasaan atas tanah yang diatur dalam hukum tanah (Harsono, 2007: 24).

Pelaksanaan kewenangan hak tanah oleh pemegang hak atas tanah juga dibatasi dalam Undang-Undang Nomor 5 Tahun 1960, antara lain:

a. Semua hak tanah mempunyai fungsi sosial (Pasal 6);

b. Setiap orang atau badan hukum yang mempunyai sesuatu hak tanah pertanian, pada asasnya diwajibkan untuk mengerjakan atau mengusahakan sendiri secara aktif dengan mencegah cara-cara pemerasan (Pasal 10 ayat (1));

c. Setiap pemegang hak dilarang menelantarkan tanah;

d. Pemegang hak atas tanah berkewajiban untuk memelihara tanah, termasuk menambah kesuburannya serta mencegah kerusakan adalah kewajiban tiap-tiap orang, badan hukum atau instansi yang mempunyai hubungan hukum dengan tanah itu, dengan memperhatikan pihak yang ekonomi lemah (Pasal 15).

Konsekuensi hukum dengan tidak dipergunakan tanahnya sesuai dengan keadaan dan sifat daripada haknya, sehingga tidak memberikan manfaat dan kebahagiaan bagi masyarakat dan negara, jika ditinjau dalam perspektif hukum tanah nasional dikategorikan sebagai tanah yang ditelantarkan. Selanjutnya hak atas tanah (HM, HGU, HGB) menjadi hapus sesuai dalam Pasal 27 huruf a angka 3, Pasal 34 huruf e, dan Pasal 40 huruf e Undang-Undang Nomor 5 Tahun 1960 dan pemutusan hubungan hukum serta ditegaskan sebagai tanah yang dikuasai langsung oleh negara.

\section{Penertiban Tanah Telantar}

Negara memberikan hak atas tanah atau hak pengelolaan kepada pemegang hak untuk diusahakan, dipergunakan, dan dimanfaatkan serta dipelihara dengan baik selain untuk kesejahteraan bagi pemegang haknya juga harus ditujukan untuk kesejahteraan masyarakat, bangsa, dan negara (Penjelasan Peraturan Pemerintah Nomor 11 Tahun 2010). 
Pemberian hak atas tanah diiringi kewajiban-kewajiban dan sesuai dengan surat keputusan pemberian haknya. Karena itu pemegang hak dilarang menelantarkan tanahnya, dan jika pemegang hak menelantarkan tanahnya, telah mengatur akibat hukumnya yaitu hapusnya hak atas tanah yang bersangkutan dan pemutusan hubungan hukum serta ditegaskan sebagai tanah yang dikuasai langsung oleh negara.

Penelantaran tanah harus dicegah dan ditertibkan untuk mengurangi atau menghapus dampak negatifnya, seperti penelantaran tanah makin menimbulkan kesenjangan sosial, ekonomi, dan kesejahteraan rakyat serta menurunkan kualitas lingkungan. Untuk menciptakan perombakan struktur yang timpang, terutama dalam hal kepemilikan dan penguasaan sumber daya alam khususnya tanah. Oleh karena itu, perlu dilakukan penataan kembali untuk mewujudkan tanah sebagai sumber kesejahteraan rakyat.

Secara teknis, mekanisme pengaturan tanah telantar oleh pemerintah telah diatur lebih lanjut dalam Peraturan Pemerintah Nomor 11 Tahun 2010 tentang Penertiban dan Pendayagunaan Tanah Telantar. Dalam ketentuan Pasal 2 telah ditegaskan: "Objek penertiban tanah telantar meliputi tanah yang sudah diberikan hak oleh negara berupa Hak Milik, Hak Guna Usaha, Hak Guna Bangunan, Hak Pakai dan Hak Pengelolaan, atau dasar penguasaan atas tanah yang tidak diusahakan, tidak dipergunakan, atau tidak dimanfaatkan sesuai dengan keadaannya atau sifat dan tujuan pemberian hak atau dasar penguasaannya." Namun pada Pasal 3 adanya pengecualian objek penertiban tanah telantar terhadap tanah Hak Milik atau Hak Guna Bangunan atas nama dan tanah yang dikuasai pemerintah baik secara langsung maupun tidak langsung dan sudah berstatus maupun belum berstatus Barang Milik Negara/Daerah yang tidak sengaja tidak dipergunakan sesuai dengan keadaan atau sifat dan tujuan pemberian haknya.

Tahapan-tahapan penertiban tanah telantar diatur dalam Pasal 4 sampai dengan Pasal 13 Peraturan Pemerintah Nomor 11 Tahun 2010 yang pada intinya membagi tahapan sebelum penetapan tanah telantar diterbitkan, yaitu:

a. Identifikasi dan penelitian oleh Kepala Kantor Wilayah BPN Provinsi dan oleh Panitia (Pasal 4 sampai dengan Pasal 7);

b. Peringatan oleh Kepala Kantor Willayah BPN Provinsi kepada Pemegang Hak (Pasal 8);

c. Penetapan tanah telantar oleh Kepala BPN atas usul Kepala Kantor Wilayah BPN Provinsi (Pasal 8 sampai dengan Pasal 13).

Tahapan-tahapan ini diperjelas dalam Pasal 3 Peraturan Kepala BPN RI Nomor 4 Tahun 2010 menjadi empat bagian tahapan penertiban tanah telantar, yaitu: pertama, inventarisasi tanah hak atau dasar penguasaan atas tanah yang terindikasi telantar; kedua, identifikasi dan penelitian tanah terindikasi telantar; ketiga, peringatan terhadap pemegang hak; keempat, penetapan tanah telantar.

Tata cara/prosedur dalam penertiban tanah telantar adalah titik krusial apabila terdapat gugatan atas penetapan tanah telantar, dalam banyak kasus gugatan di aspek prosedur terdapat tahapan-tahapan yang tidak dipatuhi yang mengakibatkan pembatalan dan pencabutan surat keputusan penetapan tanah telantar.

Apabila aspek prosedur mengandung cacat yuridis dari segi prosedur, maka dari segi substansi pengadilanpun tidak perlu dipertimbangkannya lagi dan dianggap surat keputusan penetapan tanah 
telantar melanggar asas-asas umum pemerintahan yang baik. Terhadap tanah bekas tanah telantar dilakukan pendayagunaan sebagaimana diatur dalam Peraturan Kepala BPN RI Nomor 5 Tahun 2011.

Tanah negara bekas tanah telantar tersebut akan dialokasikan secara nasional untuk kepentingan masyarakat dan negara melalui reforma agraria, program strategis negara, dan cadangan negara lainnya. Selanjutnya tanah yang diusulkan untuk ditetapkan sebagai tanah telantar dinyatakan dalam keadaan status quo sejak tanggal pengusulan. Terhadap tanah telantar berstatus quo tidak dapat dilakukan perbuatan hukum atas tanah.

\section{METODE}

Tulisan ini merupakan penelitian atas Putusan Nomor 24/G/2013/PTUN.JKT tentang Keputusan Penetapan Tanah Telantar. Pendekatan masalah yang digunakan dalam penelitian ini adalah pendekatan normatif dengan tipe judicial case study yaitu pendekatan studi kasus hukum karena suatu konflik yang tidak dapat diselesaikan oleh para pihak berkepentingan sehingga diselesaikan melalui putusan pengadilan (Muhammad, 2004: 149).

Pengumpulan data dilakukan dengan studi pustaka dan studi dokumen yang berkaitan dengan tema penelitian dengan menggunakan: a) bahan primer, yang mencakup peraturan perundangundangan dan putusan pengadilan yang berkaitan dengan pokok permasalahan penelitian; dan b) bahan sekunder, yaitu melakukan serangkaian kegiatan studi dokumentasi dengan cara mengkaji literatur-literatur termasuk dari hasilhasil penelitian serta dilakukan juga studi dokumen pengkajian informasi tertulis data yang tidak dipublikasikan secara umum tetapi boleh diketahui oleh pihak tertentu seperti bahan tayangan (slide dalam bentuk power point). Berdasarkan data tersebut akan dilakukan analisis kualitatif yakni suatu cara penelitian yang menghasilkan data deskriptif analitis.

\section{HASIL DAN PEMBAHASAN}

\section{A. Penafsiran Pengertian dan Surat Peringatan tentang Tanah Telantar}

Berdasarkan data dari Direktorat Jenderal Penertiban dan Pendayagunaan Tanah Telantar Kementerian ATR/BPN menyajikan data tanah yang terindikasi telantar yang menjadi objek perkara di pengadilan tata usaha negara dengan luasan 51,679.7038 Ha. Sebagian besar perkara tanah telantar di pengadilan tata usaha negara dimenangkan oleh pemegang hak/perusahaan. Berikut disajikan penetapan tanah telantar sebagai objek gugatan di pengadilan tata usaha negara.

Tabel 2. Penetapan Tanah Telantar sebagai Objek Gugatan di Peradilan Tata Usaha Negara

\begin{tabular}{|c|c|c|c|c|c|}
\hline No. & Provinsi & Subjek Hak & $\begin{array}{c}\text { Luas Telantar } \\
\text { (Ha) }\end{array}$ & $\begin{array}{c}\text { Nomor Putusan Pengadilan } \\
\text { Tingkat Pertama, Banding, } \\
\text { Kasasi, dan PK }\end{array}$ & $\begin{array}{l}\text { Isi Putusan } \\
\text { TUN }\end{array}$ \\
\hline \multirow[t]{2}{*}{1.} & Banten & $\begin{array}{l}\text { PT Pondok } \\
\text { Kalimaya }\end{array}$ & 235,6400 & $\begin{array}{ll}\text { 1. } & \text { 13/G/2012/PTUN-SRG } \\
\text { 2. } & \text { 251/B/2012/PT.TUN.JKT } \\
\text { 3. } 260 \mathrm{~K} / \mathrm{TUN} / 2013\end{array}$ & $\begin{array}{c}\text { Membatalkan } \\
\text { SK }\end{array}$ \\
\hline & & $\begin{array}{l}\text { PT Pasetran } \\
\text { Wanarattindo }\end{array}$ & 66.4000 & $\begin{array}{c}\text { 1. } 16 / \mathrm{G} / 2012 / \mathrm{PTUN}-\mathrm{SRG} \\
\text { 2. } 265 / \mathrm{B} / 2012 / \mathrm{PT} . \mathrm{TUN} . J K T \\
\text { 3. } 295 \mathrm{~K} / \mathrm{TUN} / 2013\end{array}$ & idem \\
\hline
\end{tabular}




\begin{tabular}{|c|c|c|c|c|c|}
\hline 2. & Sulsel & $\begin{array}{l}\text { PT Seko Fajar } \\
\text { Plantation }\end{array}$ & $23,712,0000$ & 35/G/2012/PTUN-JKT & idem \\
\hline 3. & Babel & $\begin{array}{l}\text { PT Krama Yudha } \\
\text { S }\end{array}$ & $3,368,5000$ & 58/G/2012/PTUN-JKT & idem \\
\hline 4. & Kepri & $\begin{array}{l}\text { PT Sunnymas } \\
\text { Prima Agung }\end{array}$ & $2,787,1510$ & $\begin{array}{l}\text { 1. 118/G/2012/PTUN-JKT } \\
\text { 2. 33/B/2013/PT.TUN.JKT }\end{array}$ & idem \\
\hline 5. & Sulbar & PT Unggul Widya & 226,5200 & 28/G/2013/P.TUN.MKS & idem \\
\hline 6. & Kalbar & PT Kebunaria & $1,049.6160$ & $\begin{array}{l}\text { 1. } 118 / \mathrm{G} / 2013 / \mathrm{PTUN}-J K T \\
\text { 2. } 315 / \mathrm{B} / 2013 / \mathrm{PT} . T U N . J K T \\
\text { 3. } 391 \mathrm{~K} / \mathrm{TUN} / 2014 \\
\text { 4. } 137 \mathrm{PK} / \mathrm{TUN} / 2016\end{array}$ & idem \\
\hline 7. & Jambi & PT Jambi Agro W & $5,352.8000$ & - & idem \\
\hline \multirow[t]{2}{*}{8.} & Sulteng & PT SPM & 163,1366 & 273/G/2014/PTUN-JKT & idem \\
\hline & & PT Sinar Waluyo & 63,4320 & 275/G/2014/PTUN-JKT & idem \\
\hline 9. & Sumsel & PT Mitra Aneka R & $4,414,2600$ & - & idem \\
\hline 10. & Sumut & $\begin{array}{l}\text { PT PP London } \\
\text { Sumatera }\end{array}$ & $1,077.5092$ & 125/G/2013/PTUN-JKT & idem \\
\hline 11. & Kalteng & $\begin{array}{c}\text { PT Sumber } \\
\text { Mahardika Graha }\end{array}$ & $8,344,6300$ & 24/G/2013/ PTUN.JKT & idem \\
\hline 12. & Jateng & $\begin{array}{c}\text { PT Perkebunan } \\
\text { Tratak Batang }\end{array}$ & 82.4400 & 25/G/2013/PTUN-JKT. & BPN Menang \\
\hline 13. & Jatim & $\begin{array}{l}\text { PT Mojokerto } \\
\text { Industrial Park }\end{array}$ & 152.6590 & $\begin{array}{c}\text { 1. 62/G/2013/PTUN.SBY } \\
\text { 2. 01/B/2014/PT.TUN.SBY } \\
\text { 3. } 286 \text { K/TUN/2014 } \\
\text { 4. } 90 \text { PK/TUN/2016 }\end{array}$ & BPN Menang \\
\hline \multirow[t]{2}{*}{14.} & Sumbar & PT Para Andalas S & 183.0000 & 25/G/2014/PTUN.JKT & BPN Menang \\
\hline & & Jumlah & $51,679.7038$ & & \\
\hline
\end{tabular}

Sumber: Diolah dari direktori putusan Mahkamah Agung dan Direktorat Jenderal Penertiban dan Pendayagunaan Tanah Telantar Kementerian ATR/BPN.

Pembatalan surat keputusan tanah telantar oleh pengadilan disebabkan tahapan-tahapan secara prosedur/formal tidak dipatuhi dengan benar sebagaimana diatur dalam Pasal 4 sampai dengan Pasal 13 Peraturan Pemerintah Nomor 11 Tahun 2010. Kesalahan prosedur dalam keputusan penetapan tanah telantar bukan bersifat subtansi, hanya bersifat administrasi/surat menyurat, seperti tidak adanya laporan dalam bentuk tertulis, surat tidak sesuai format yang ditentukan, kesalahan tanggal dalam surat, beda orang dalam indentifikasi karena tidak sesuai dengan surat tugas. Seyogianya dalam kasus-kasus seperti ini hakim bisa menoleransi pelanggaran prosedural asalkan tidak melanggar substansi keadilan. Bahkan secara subtansi hakim mengetahui dalam persidangan di lokasi setempat/objek sengketa bahwa benar tanah tersebut ditelantarkan, akan tetapi hakim dalam putusannya membatalkan surat keputusan, karena aspek prosedurnya terdapat tahapan-tahapan yang dipatuhi.

Berbeda dengan kasus-kasus yang dimenangkan oleh BPN pada umumnya pemegang hak atas tanah dengan sengaja menelantarkan tanahnya karena tidak menggunakan tanah sesuai dengan keadaan atau sifat dan tujuan haknya, 
dengan sengaja tanahnya ditinggalkan begitu saja, sudah tidak mempuyai karyawan maupun pabrik karena ketidakmampuan mendayagunakan secara finansial, serta tanahnya sengketa dengan masyarakat sekitar. Dari beberapa putusan di atas yang menjadi fokus kajian ini adalah putusan pengadilan tata usaha negara mengenai surat keputusan penetapan tanah telantar PT SMG. Perdebatan dalam pokok perkara adalah mengenai pengertian tanah telantar dan surat peringatan kepada pemegang hak yang jangka waktunya yang sangat pendek hanya tiga bulan sampai dengan peringatan ketiga.

\section{Pengertian Tanah Telantar}

PT SMG menguraikan permasalahanpermasalahan HGU yang dimilikinya tidak diusahakan, tidak dipergunakan, atau tidak dimanfaatkan sesuai dengan keadaannya, permasalahannya karena:

a. Terdapat hambatan pemanfaatan tanah HGU sesuai dengan peruntukannya karena adanya perubahan kebijakan terkait status kawasan yang dalam proses permohonan pelepasan kawasan hutan serta adanya perbedaan pendapat hukum antara Pemerintah Daerah Kalimantan Tengah dengan Kementerian Kehutanan tentang status ataupun peraturan keadaan yang demikian tidak dapat disimpulkan sebagai penelantaran tanah;

b. Permasalahan tata ruang yang menghambat pembangunan kebun;

c. Terdapatkendalaterhadap pembebasan lahan dan proses ganti rugi dengan masyarakat setempat disebabkan karena adanya konflik antar masyarakat mengenai batas desa.
Apakah permasalahan yang dihadapi PT SMG dapat dikategorikan sebagai tanah telantar? Terhadap permasalahan tersebut di atas, majelis hakim pada pokoknya berpendapat dalam pertimbangan hukumnya, yaitu:

a. Dalam identifikasi dan penelitian tidak sesuai ketentuan Pasal 7 huruf d Peraturan Pemerintah Nomor 11 Tahun 2010 yang menyatakan bahwa identifikasi dan penelitian harus melaksanakan pemeriksaan fisik di lapangan, karena yang bersangkutan tidak masuk di areal yang menjadi objek sengketa; tidak mengerjakan tanah secara maksimal karena adanya surat perintah dari Bupati Lamandau perihal penghentian pembukaan lahan dan adanya konflik antar masyarakat; dan adanya penetapan lahan tersebut sebagai kawasan hutan sehingga harus dilakukan pelepasan kawasan hutan.

b. Sesuai keterangan ahli yang bernama Arie Sukanti Hutagalung, menerangkan bahwa apabila di areal tersebut ditentukan sebagai kawasan hutan maka harus mendapatkan izin pelepasan hutan dari instansi terkait karena sebelum HGU dikeluarkan oleh BPN tentunya mempertimbangkan hasil penelitian panitia yang menyatakan bahwa sudah sesuai dengan RTRWP maka dikeluarkanlahHGU, sehingga apakahtanah tersebut bisa dinyatakan tanah telantar atau tidak hal tersebut perlu dipertimbangkan karena konsep teori tanah telantar dalam Peraturan Pemerintah Nomor 11 Tahun 2010 adalah dengan sengaja menelantarkan tanahnya sehingga dalam konteks demikian tidaklah termasuk sebagai tanah telantar dan apabila berdasarkan rencana tata ruang wilayahnya, kalau memang disediakan untuk perkebunan memang harus 
dipergunakan tetapi kalau itu ternyata masih dikembalikan lagi menjadi kawasan hutan, karena undang-undang yang baru setiap kali pemerintah daerah bisa mengubah RTRWP-nya itu menyatakan areal tersebut sebagai kawasan hutan berarti harus dilepas dulu, dengan mendapatkan izin kehutanan, baru bisa beraktivitas walaupun haknya sudah lahir, hubungan hukumnya sudah ada tetapi untuk beraktivitas pada suatu tanah yang termasuk kawasan hutan tidak diperbolehkan dalam undang-undang kehutanan.

Berdasarkan pertimbangan hukum tersebut di atas, maka tidak patut penggugat dinyatakan menelantarkan areal lahan dari kedua HGU yang diberikan oleh tergugat tersebut. Majelis hakim berkesimpulan bahwa tergugat patut dinilai dalam menerbitkan objek sengketa telah bertentangan dengan peraturan perundang-undangan yang berlaku dan asas-asas umum pemerintahan yang baik khususnya asas kecermatan.

Penafsiran pengertian tanah telantar dapat dilihat dalam penjelasan Pasal 27 UndangUndang Nomor 5 Tahun 1960 yang menyatakan: "Tanah ditelantarkan kalau dengan sengaja tidak dipergunakan sesuai dengan keadaannya atau sifat dan tujuan daripada haknya." Pengertian tanah telantar berdasarkan Pasal 2 Peraturan Pemerintah Nomor 11 Tahun 2010 jo. Pasal 1 angka 6 Peraturan Kepala BPN RI Nomor 4 Tahun 2010 menyebutkan:

"Objek penertiban tanah telantar meliputi tanah yang sudah diberikan hak oleh negara berupa Hak Milik, Hak Guna Usaha, Hak Guna Bangunan, Hak Pakai, dan Hak Pengelolaan, atau dasar penguasaan atas tanah yang tidak diusahakan, tidak dipergunakan, atau tidak dimanfaatkan sesuai dengan keadaannya atau sifat dan tujuan pemberian hak atau dasar penguasaannya."

Pasal 3 huruf a Peraturan Pemerintah Nomor 11 Tahun 2010 yang berbunyi:

"Tidak termasuk objek penertiban tanah telantar sebagaimana dimaksud dalam Pasal 2 adalah tanah Hak Milik atau Hak Guna Bangunan atas nama perseorangan yang secara tidak sengaja tidak dipergunakan sesuai dengan keadaan atau sifat dan tujuan pemberian haknya."

Penjelasan Pasal 3 huruf a Peraturan Pemerintah Nomor 11 Tahun 2010 yang dimaksud dengan tidak sengaja tidak dipergunakan sesuai dengan keadaan atau sifat dan tujuan pemberian haknya. Penjelasan resmi pasal-pasal tersebut tidak menjelaskan lebih lanjut apa yang dimaksud dengan sengaja, tidak diusahakan, tidak dipergunakan atau tidak dimanfaatkan sesuai dengan keadaan atau sifat dan tujuan pemberian hak atau dasar penguasaannya. Sehingga, bisa ditafsirkan bermacam-macam tanpa batasan yang jelas.

Filosofi Peraturan Pemerintah Nomor 11 Tahun 2010 adalah "dengan sengaja" lawan katanya "tidak sengaja." Tidak adanya penjelasan resmi tentang pengertian-pengertian tersebut, menjadi perdebatan dalam kasus penetapan tanah telantar sebagai objek perkara di pengadilan tata usaha negara.

Ketidaksengajaan untuk tidak mengusahakan, menggunakan atau tidak memanfaatkan tanah karena disebabkan:

a. Adanya pendudukan atau klaim dari masyarakat;

b. Akibat terjadinya krisis moneter;

c. Adanya sengketa ekternal masyarakat dengan perusahaan maupun perselisihan internal para pemegang saham; 
d. Faktor tumpang tindih peraturan dan kebijakan antar instansi yang berbeda-beda;

e. Karena perubahan Rencana Tata Ruang Wilayah.

Permasalahan-permasalahan

ini

dikategorikan sebagai unsur ketidaksengajaan yang mengakibatkan tanah tidak dipergunakan sesuai dengan keadaan atau sifat dan tujuan pemberian haknya terkendala untuk sementara waktu.

Pengertian yang dimaksud tidak digunakan, tidak dimanfaatkan, dan tidak diusahakan sesuai dengan sifat dan tujuan pemberian hak adalah tanah yang diindikasikan tidak dimanfaatkan, tidak digunakan atau tidak dimanfaatkan, seperti tidak diurus izinnya, tidak dikuasai atau tidak dibangun sesuai tujuan pemberian haknya. Sesuai dengan keadaan bisa juga diartikan kondisi dan keadaan setempat misalnya terkait tata ruang wilayah, bisa juga keadaan fisik tanah misalnya, tanahnya kosong, semak belukar. Sehingga, dapat dikatakan tidak dimanfaatkan sesuai keadaannya.

Menurut sifat dan tujuannya atau disebut juga "sesuai peruntukannya" dalam Pasal 2 Peraturan Pemerintah Nomor 11 Tahun 2010 beserta penjelasannya dan Pasal 1 ayat (6) Peraturan Kepala BPN RI Nomor 4 Tahun 2010. Misalnya peruntukannya seharusnya untuk HGU perkebunan tidak digunakan untuk perkebunan atau peruntukannya untuk tanaman sawit tetapi yang ditanam tanaman karet.

Vollenhoven (1975: 8) memberikan istilah tanah telantar dengan de woeste gronden yang diartikan "tanah-tanah liar" atau tidak diusahakan. De woeste gronden lawan katannya adalah de bouwvelden yang diartikan sebagai tanah-tanah pertanian yang telah diusahakan oleh seseorang.
Pengertian tanah telantar menurut Harsono (2008: 331 dan 336) memandang tanah telantar lebih mengarah pada terjadinya peristiwa hukum karena perbuatan manusia, sehingga hak atas tanah menjadi hapus. Hapusnya hak atas tanah harus dinyatakan dengan surat keputusan oleh pejabat yang berwenang, sebagai sanksi terhadap tidak dipenuhinya oleh pemegang hak yang bersangkutan kewajiban tertentu atau dilanggarnya sesuatu larangan.

Parlindungan (1990: 7) mengemukakan konsep tanah telantar dengan merujuk pada hukum adat yaitu sesuai dengan karakter tanah telantar (kondisi fisik) yang telah berubah dalam waktu tertentu maka haknya gugur, tanah kembali pada hak ulayat. Pendapat lain yang dikemukakan oleh Nasution adalah tanah telantar yang oleh subjek hukum yang menguasainya dengan sengaja tidak dipergunakan sesuai dengan keadaannya atau sifat dari tujuan haknya, peruntukannya dan atau kemampuan alamiahnya (Astina, 1997: 27).

Tanah telantar apabila ditinjau dari asal kata terdiri dari dua kata yaitu "tanah" dan "telantar." Tanah mengandung pengertian sebagaimana dimaksud dalam Pasal 4 ayat (2) Undang-Undang Nomor 5 Tahun 1960 yaitu permukaan bumi yang dalam penggunaannya meliputi juga tubuh bumi dan air serta ruang yang ada di atasnya, sekedar diperlukan untuk kepentingan yang langsung berhubungan dengan penggunaan tanah tersebut. Sedangkan "telantar" mengandung pengertian tanah yang tidak dipelihara, tidak dirawat, tidak terurus, tidak dikerjakan, terbelengkai, tanah kosong/tidur, maka pengertian yang demikian dikategorikan sebagai tanah yang ditelantarkan.

Tanah yang dibiarkan tidak dimanfaatkan juga dapat dikategorikan sebagai tanah yang tidak telantar, dalam arti penelantaran tanah 
juga bisa menguntungkan manusia, misalnya manfaatnya termasuk revegetasi pasif dan reboisasi aktif, pengaturan air, pemulihan tanah/ mempertahankan kesuburan tanah, siklus nutrisi dan peningkatan keanekaragaman. Demikian juga dengan sebagian tanah seperempat atau setengah tidak dimanfaatkan karena ada beberapa tanaman membutuhkan ruang kosong tidak ditanami untuk menjaga kualitas yang bermutu. Konsep teori tanah telantar adalah "dengan sengaja" menelantarkan tanahnya.

Penafsiran pengertian tanah telantar dalam konteks Putusan Nomor 24/G/2013/PTUN. JKT harus ada unsur kesengajaan. Adanya hambatan-hambatan pemanfaatan tanah HGU seperti karena adanya perubahan status kawasan hutan, permasalahan tata ruang, serta kendala terhadap pembebasan lahan dan proses ganti rugi dengan masyarakat setempat disebabkan karena adanya konflik antar masyarakat mengenai batas desa. Adanya hambatan-hambatan tersebut dikategorikan sebagai unsur ketidaksengajaan dan tidak dapat dikategorikan sebagai tanah telantar.

\section{Penafsiran Mengenai Surat Peringatan}

Berdasarkan hasil identifikasi dan penelitian dari Panitia C Kepala Kantor Wilayah BPN memberitahukan kepada pemegang hak sekaligus memberikan peringatan tertulis pertama, kedua, dan ketiga masing-masing dalam jangka waktu satu bulan (Pasal 8 Peraturan Pemerintah Nomor 11 Tahun 2010).

Pemegang hak diberikan kesempatan untuk melakukan tindakan konkret yaitu mengusahakan tanahnya sesuai keadaan atau sifat dan tujuan pemberian haknya, mengajukan permohonan perubahan hak dalam hal tanah yang digunakan tidak sesuai dengan sifat dan tujuan pemberian haknya, mengajukan permohonan hak untuk dasar penguasaan atas tanah mengusahakan, menggunakan atau memanfaatkan tanahnya sesuai izin dari pejabat yang berwenang, dalam masa peringatan pertama, kedua, ketiga di mana pemegang hak wajib menyampaikan laporan kemajuan dan pemanfaatan tanah kepada Kepala Kantor Wilayah BPN dengan tembusan Kepala Kantor Pertanahan (Pasal 15 dan 16 Peraturan Kepala BPN RI Nomor 4 Tahun 2010).

Menurut Arie Sukanti Hutagalung sebagai saksi ahli yang diajukan PT SMG menyatakan:

Bahwa yang dimaksud dengan hal-hal konkret dalam Pasal 14 ayat (3) Peraturan Kepala BPN RI Nomor 4 Tahun 2010 adalah harus disebutkan hal-hal yang harus dilakukan, misalnya harus mengajukan pelepasan hutan, harus mulai melakukan kegiatan land clearing, harus mulai menanam. Dalam hal BPN mengetahui ada perubahan kawasan lahan, maka harusnya dimulai dengan teguran untuk segera mengajukan izin pelepasan kawasan hutan.

Tindakan konkret yang dilakukan oleh PT SMG berupa land clearing, penanaman kebun pada areal yang sudah terbuka serta melaksanakan pengamanan dan monitoring areal kebun, yang ditujukan dengan berkurangnya areal yang belum tertanam. Dalam konteks ini apakah sudah dapat dikategorikan sudah melaksanakan surat peringatan. Surat peringatan dalam jangka waktu satu bulan setelah ditegur adalah harus ada suatu progress terhadap suatu kegiatan kemajuan daripada sebelum ditegur.

Pemegang hak setelah menerima peringatan biasanya melakukan land clearing yang dianggap telah melaksanakan teguran dan tidak perlu surat teguran yang kedua kecuali dia tidak melaksanakan teguran sama sekali, 
berbeda dengan pemerintah yang menganggap land clearing tidak termasuk dalam kegiatan mengusahakan tanahnya.

Land clearing tidak mungkin seluruhnya selesai dalam jangka waktu satu atau dua bulan yang luasnya ribuan bahkan puluhan ribu, jadi sepanjang sudah dimulai dilakukan kegiatan awal maka dianggap sudah melaksanakan teguran dan tidak perlu surat teguran yang kedua atau ketiga kecuali dia tidak melaksanakan teguran sama sekali. Di sisi lain, proses pelaksanaan land clearing memerlukan kegiatan-kegiatan seperti mempersiapkan kontrak kerja atau kontraktor untuk membersihkan lahan, melakukan survei ke lokasi lapangan sebelum melakukan pekerjaan seperti status lahan, medannya, dan juga mempersiapkan alatnya bulldozer, excavator, juga persiapan pembuatan camp, mobilisasi alatalat, kemudian melakukan perintisan lahan yang memerlukan waktu yang lama.

Kegiatan land clearing oleh BPN tidak dianggap sebagai tindakan konkret mengusahakan tanahnya sesuai keadaan atau sifat dan tujuan pemberian haknya. Pertanyaan yang lazim diajukan BPN adalah kenapa tidak dari dulu tidak dikerjakan setelah mendapat hak atas tanahnya? Tentunya beragam jawabannya sesuai dengan faktor kondisinya. Misalnya, pertama, karena faktor fisik alamiah tanah, seperti faktor kesuburan tanah, rendahnya kesediaan air, lokasi yang rawan banjir, tanah berada lereng yang terjal; kedua, faktor sengketa tanah baik antar masyarakat dengan perusahaan maupun sengketa antar pemegang saham; ketiga, faktor ekonomi, kemampuan perusahaan untuk mengusahakan atau memanfaatkan tanah; keempat, faktor kebijakan pemerintah, misalnya dalam perolehan hak atas tanah harus ada izin lokasi atau pelepasan kawasan hutan, kebijakan antar instansi yang berbeda-beda; kelima, karena perubahan tata ruang.

Menurut Winoto (2010: 1-5) penyebab penelantaran tanah, pertama adalah karena ketidakmampuan mendayagunakan, baik secara finansial maupun non-finansial; kedua adalah karena pemiliknya berspekulasi pada saat membeli dan tidak memiliki gambaran yang jelas tentang penggunaannya; ketiga adalah bahwa tanah tersebut sengaja ditelantarkan tapi sertifikatnya dipakai untuk mencari pinjaman. Penyebab lainnya tanah ditelantarkan seperti kesalahan teknis dalam pemberian hak, misalnya, dalam pemberian HGU, areal konservasi maupun areal dengan topografi yang curam tidak dienclave dari HGU, dan karena unsur kesengajaan yaitu unsur spekulasi karena nilai tanah yang terus meningkat.

Jangka waktu pemberian peringatan, apabila dibandingkan dengan Peraturan Pemerintah Nomor 36 Tahun 1998, pelaksanaannya di kantor BPN yang membantu pelaksanaannya dibentuk tim penilaian, jangka waktu peringatan I, II, dan III dengan jeda masing-masing satu tahun. Sedangkan dalam Peraturan Pemerintah Nomor 11 Tahun 2010, pelaksanaannya di Kanwil BPN Provinsi, yang membantu pelaksanaan adalah bagian c dan jangka waktu peringatan I, II, dan III dengan jeda antar peringatan hanya satu bulan.

Perbedaan yang signifikan adalah Peraturan Pemerintah Nomor 36 Tahun 1998 tidak ada target, sedangkan Peraturan Pemerintah Nomor 11 Tahun 2010 ada target yang harus dilaksanakan sesuai target dari program pemerintah. Untuk mencapai target seringkali pemerintah mengalami kesulitan untuk mengambil kembali tanah yang dikategorikan sebagai tanah telantar, hanya sedikit sekali tanah telantar yang dapat dikuasai kembali 
oleh negara. Sampai saat ini TORA dari tanah telantar baru 23 ribu hektar yang teridentifikasi ( $\pm 5 \%$ dari target 400 ribu hektar), sehingga akan sulit untuk mencapai target (Kementerian Koordinator Bidang Perekonomian, 2017).

Secara umum, kesulitan/hambatan dalam penertiban tanah telantar sebagai objek sengketa di pengadilan tata usaha negara adalah:

a. Pemilik dan alamat pemegang hak yang telahberganti/pindahyang tidakmelaporkan kepada instansi terkait, sehingga menyulitkan dalam memyampaikan surat pemberitahuan/peringatan dan kesulitan dalam identifikasi dan penelitian tanah karena tidak dihadiri oleh pemegang hak;

b. Kesulitan mengetahui penyebab tanah ditelantarkan;

c. Kesulitan menetapkan luasan tanah dan batas-batas tanah terindikasi telantar;

d. Faktor sumber daya manusia yaitu kemampuan secarayuridisuntukmemahami ketentuan peraturan mengenai penertiban dan pendayagunaan tanah telantar dalam pengadilan tata usaha negara;

e. Pola anggaran hanya berbasis Surat Perintah Perjalanan Dinas dalam penertiban dan pendayagunaan tanah telantar belum cukup memadai, tidak sebanding tanah telantar yang akan ditertibkan bernilai miliaran rupiah bahkan triliunan.

\section{B. Implikasi Pembatalan Surat Keputusan Penetapan Tanah Telantar}

Berdasarkan ketentuan Pasal 53 ayat (2) Undang-Undang Nomor 9 Tahun 2004, dasar pengujian oleh pengadilan terhadap keputusan tata usaha negara yang digugat adalah Keputusan Tata Usaha Negara yang digugat itu bertentangan dengan peraturan perundang-undangan yang berlaku dan bertentangan dengan asas-asas umum pemerintahan yang baik.

Pengertian bertentangan dengan peraturan perundang-undangan yang berlaku oleh pengadilan diterjemahkan dalam pengertian bertentangan dengan ketentuan yang bersifat prosedur/formal, substansi/materiel dan keputusan dikeluarkan oleh pejabat yang berwenang.

Hadjon mengutarakan wewenang, prosedur, dan substansi, ketiga aspek hukum merupakan landasan hukum untuk dapat dikatakan suatu ketetapan atau keputusan tersebut sah. Pertama, aspek wewenang dalam hal ini artinya bahwa pejabat yang mengeluarkan ketetapan tersebut memang mempunyai kewenangan sesuai dengan ketentuan yang berlaku untuk itu; kedua, aspek prosedur, berarti bahwa ketetapan atau keputusan tersebut dikeluarkan sesuai dengan tata cara yang disyaratkan dan bertumpu kepada asas keterbukaan pemerintah; ketiga, aspek substansi, artinya menyangkut objek ketetapan atau keputusan (Matutu et al., 2004: 109-159). Alasan penggugat pada dasarnya adalah persoalan keabsahahan dari keputusan tata usaha negara yang menyangkut wewenang, prosedur, dan subtansi (Hadjon, 2008: 330).

Kaitannya dengan sengketa keputusan penetapan tanah telantar merupakan kompetensi pengadilan tata usaha negara. Keputusan adalah salah satu objek studi hukum administrasi yang menjadi instrumen yuridis pemerintah dalam melakukan tindakan-tindakan pemerintah. Aspek prosedur dalam penertiban tanah telantar adalah titik krusial apabila terdapat gugatan atas 
penetapan tanah telantar, dalam banyak kasus gugatan di aspek prosedur terdapat tahapantahapan yang tidak dipatuhi yang mengakibatkan pembatalan dan pencabutan surat keputusan penetapan tanah telantar. Apabila aspek prosedur mengandung cacat yuridis dari segi prosedur, maka dari segi substansi pengadilanpun tidak perlu mempertimbangkannya lagi dan dianggap surat keputusan penetapan tanah telantar bertentangan dengan peraturan perundangundangan yang berlaku dan asas-asas umum pemerintahan yang baik.

Telah dijelaskan di muka, keputusan penetapan talah telantar didominasi oleh kekalahan yang mengakibatkan pencabutan dan pembatalan surat keputusan penetapan tanah telantar mengakibatkan terhambatnya pencapaian berbagai tujuan program pembangunan, rentannya ketahanan pangan, dan ketahanan ekonomi nasional, tertutupnya akses sosialekonomi masyarakat khususnya petani pada tanah, serta terusiknya rasa keadilan dan harmoni sosial (Penjelasan Peraturan Pemerintah Nomor 11 Tahun 2010). Juga tidak dapat didayagunakan untuk kepentingan masyarakat dan negara, melalui reforma agraria dan program strategis negara serta untuk cadangan negara lainnya sebagaimana diatur dalam Pasal 15 Peraturan Pemerintah Nomor 11 Tahun 2010.

Hal ini juga berimplikasi terhadap: pertama, tidak tercapainya kebijakan nawa cita pemerintahan Jokowi-JK yaitu redistribusi tanah 9 juta hektar sebagai salah satu tanah objek reforma agraria, salah satunya adalah tanah HGU habis dan tanah telantar seluas 0,4 juta hektar. Karena saat ini tanah yang telah dikuasai dan/atau dimiliki baik yang sudah ada hak atas tanahnya banyak dalam keadaan telantar.
Kedua, tidak terlaksananya pendayagunaan tanah negara diperoleh dari tanah negara bekas tanah telantar yang dialokasikan secara nasional untuk kepentingan masyarakat dan negara melalui: (i) reforma agraria, merupakan pelaksanaan konsep redistribusi tanah untuk masyarakat; (ii) program strategis negara, dimanfaatkan antara lain untuk pengembangan sektor pangan, energi, perumahan rakyat; dan (iii) cadangan negara, dilaksanakan untuk memenuhi kebutuhan tanah untuk kepentingan pemerintah, pertahanan dan keamanan, kebutuhan tanah akibat adanya bencana alam, relokasi dan pemukiman kembali masyarakat yang terkena pembangunan untuk kepentingan umum.

Peruntukan tanah bekas tanah telantar tersebut harus dalam keadaan clear, dalam artian tanah tersebut tidak dalam sengketa fisik maupun sengketa yuridis. Permasalahan redistribusi dalam bentuk reforma agraria adalah masalah yang pelik dan rumit. Pelbagai teori, strategi, konsep, dan gagasan telah dipaparkan oleh para pakar agraria, tetapi tidak mudah dilaksankan dalam praktik. Berbagai kebijakan dan keputusan yang telah dilaksanakan oleh pemerintah, bahkan pemerintahan telah silih berganti, belum bisa juga menjawab atau menyelesaikan persoalanpersoalan agraria. Bahkan, kian hari konflik agraria semakin meningkat dan masif.

Gagasan yang dipaparkan Wiradi (2000: 181-182) bahwa keberhasilan reforma agraria diperlukan prasyarat yang harus dipenuhi, yaitu: (i) kemauan politik dari elit penguasa; (ii) elit pemerintah/birokrasi yang terpisah dari elit bisnis; (iii) partisipasi aktif dari semua kelompok sosial, organisasi rakyat/tani yang pro-reform; (iv) data dasar masalah agraria yang lengkap dan teliti. Di samping empat prasyarat tadi diperlukan juga pengadilan land reform dan badan otorita 
khusus dan terpusat, bersifat independen dan hanya bertanggung jawab kepada presiden (Wiradi, 2000: 188).

Ketiga, ketimpangan kepemilikan lahan dan konflik agraria semakin tajam. Berdasarkan data ketimpangan kepemilikan aset, 56\% aset nasional dikuasai $0,2 \%$ dari jumlah penduduk (Winoto, 2010: 29). Data juga disajikan oleh Suryanto (2017) menyatakan bahwa 1,00\% penduduk mengendalikan 49,30\% sumber daya ekonomi Indonesia, Gini Ratio umum posisi Maret 2016 sebesar 0,39\%, korporasi menguasai hampir $60 \%$ lahan perkebunan kelapa sawit di Indonesia. Gini Ratio penguasaan tanah adalah sebesar $0,59 \%$. Demikian juga dengan konflik agraria, Konsorsium Pembaharuan Agraria mencatat sedikitnya telah terjadi 450 konflik agraria sepanjang tahun 2016, dengan luasan wilayah 1.265.027 hektar dan melibatkan 86.745 KK yang tersebar di seluruh provinsi di Indonesia. Perkebunan masih tetap menjadi sektor penyebab tertinggi konflik agraria (KPA, 2016).

Tidak tertutup kemungkinan di kemudian hari ketimpangan kepemilikan lahan dan konflik agraria semakit akut, kronis, dan semakin rumit untuk menyelesaikan permasalahannya. Di sisi lain timbulnya konflik-konflik agraria, yang dipicu oleh tumpang tindihnya kebijakan distribusi lahan pada masa lalu, di mana lahan-lahan negara yang diberi izin untuk dikelola, ternyata tidak seluruhnya merupakan lahan negara yang bebas kepemilikan. Menurut Zakaria et al. (2001: 71) persoalan kemiskinan tersebut berpangkal dari adanya konsentrasi atau penumpukan penguasaan tanah dan pemanfaatan tanah beserta sumber daya alamnya yang sengaja dibiarkan berkembang.

Menjawab permasalahan sebagaimana disebut di atas, dapat dilakukan adalah reforma agraria yang merupakan implementasi dari mandat TAP MPR RI Nomor IX/MPR/2001 tentang Pembaruan Agraria dan Pengelolaan Sumber Daya Alam. Dalam Pasal 2 TAP MPR RI Nomor IX/MPR/2001 ini mendefinisikan pembaruan agraria sebagai suatu proses yang berkesinambungan berkenaan dengan penataan kembali penguasaan, pemilikan, penggunaan, dan pemanfaatan sumber daya agraria, dilaksanakan dalam rangka tercapainya kepastian dan perlindungan hukum serta keadilan dan kemakmuran bagi seluruh rakyat Indonesia.

Reforma agraria dalam pandangan Winoto (2007, iii) dapat mengatasi persoalan-persoalan struktural yang mewujud dalam bentuk: (a) tingginya tingkat pengangguran; (b) tingginya tingkat kemiskinan; (c) tingginya konsentrasi aset agraria pada sebagian kecil masyarakat; (d) tingginya sengketa dan konflik pertanahan di seluruh Indonesia; (e) rentannya ketahanan pangan dan ketahanan energi rumah tangga dari sebagian besar masyarakat; (f) semakin menurunnya kualitas lingkungan hidup; dan (g) lemahnya akses sebagian terbesar masyarakat terhadap hak-hak dasar rakyat termasuk terhadap sumber-sumber ekonomi keluarga.

Rumusan Winoto (2007, v) reforma agraria sebagai land reform plus yang mengartikan reforma agraria adalah land reform di dalam kerangka mandat konstitusi, politik, dan undang-undang untuk mewujudkan keadilan dalam penguasaan, pemilikan, penggunaan, dan pemanfaatan sumber daya agraria, ditambah dengan access reform, dirumuskan reforma Agraria $=$ land Reform + Access Reform.

Untuk memastikan reforma agraria berjalan baik, tanah-tanah secara fisik dan secara hukum benar-benar ditelantarkan 
didistribusikan kepada masyarakat yang tidak memiliki tanah, sesuai dengan tujuan penertiban tanah telantar berdasarkan Peraturan Pemerintah Nomor 11 Tahun 2010 tentang Penertiban dan Pendayagunaan Tanah Telantar sebagai berikut:

"Penataan kembali untuk mewujudkan tanah sebagai sumber kesejahteraan rakyat, untuk mewujudkan kehidupan yang lebih berkeadilan, menjamin keberlanjutan sistem kemasyarakatan dan kebangsaan Indonesia, serta memperkuat harmoni sosial. Selain itu, optimalisasi pengusahaan, penggunaan, dan pemanfaatan semua tanah di wilayah Indonesia diperlukan untuk meningkatkan kualitas lingkungan hidup, mengurangi kemiskinan dan menciptakan lapangan kerja, serta untuk meningkatkan ketahanan pangan dan energi."

Dengan demikian kendala dan hambatan dalam penertiban tanah telantar tersebut harus segera diatasi, karena banyak tanah yang tersandera oleh perizinan, hak, politik dan hukum dapat ditertibkan dengan baik, dikaji dalam multiperspektif dan multisektoral terkait dengan regulasi dan kewenangan lembaga dalam penertiban tanah telantar, sehingga tanah untuk keadilan dan kesejahteraan rakyat dapat terwujud serta pendayagunaan tanah telantar dapat terlaksana dengan baik.

\section{KESIMPULAN}

Filosofi atau tujuan pelaksanaan penetapan mengenai tanah telantar adalah agar tanah dipergunakan sesuai dengan keadaannya atau sifat dan tujuan daripada haknya. Karena pemberian hak atas tanah berisikan serangkaian wewenang, kewajiban dan/atau larangan bagi pemegang haknya untuk menggunakan tanahnya. Konsekuensi hukum dengan tidak dipergunakan tanahnya sesuai dengan keadaan dan sifat daripada haknya, dikategorikan sebagai tanah yang ditelantarkan yang berakibat pemutusan hubungan hukum serta ditegaskan sebagai tanah yang dikuasai langsung oleh negara.

Berdasarkan pada pembahasan masalah yang telah diuraikan di atas, maka kesimpulannya adalah sebagai berikut:

1. Putusan Nomor 24/G/2013/PTUN.JKT menunjukkan adanya perbedaan penafsiran mengenai pengertian tanah telantar terkait dengan frase "dengan sengaja" dan "tidak sengaja." Pengertian tanah telantar dalam Peraturan Pemerintah Nomor 11 Tahun 2010 adalah "dengan sengaja" menelantarkan tanahnya.

Tanah yang dimaksud tidak digunakan, tidak dimanfaatkan dan tidak diusahakan sesuai dengan sifat dan tujuan pemberian hak adalah tanah yang diindikasikan tidak dimanfaatkan, tidak digunakan atau tidak dimanfaatkan, seperti tidak diurus izinnya, tidak dikuasai atau tidak dibangun sesuai tujuan pemberian haknya dan dilihat secara fisik tanahnya dalam kondisi yang tidak dipelihara, tidak dirawat, tidak terurus, tidak dikerjakan, terbelengkalai, semak belukar. Sedangkan masalah-masalah yang dialami pemegang hak atas nama PT SMG adalah:

a. Adanya pendudukan atau klaim dari masyarakat atas tanah;

b. Akibat terjadinya krisis moneter;

c. Adanya sengketa;

d. Faktor tumpang tindih peraturan dan kebijakan antar instansi yang berbeda-beda; 
e. Karena perubahan rencana tata ruang wilayah.

Menurut majelis hakim permasalahanpermasalahan ini dikategorikan sebagai unsur ketidaksengajaan yang mengakibatkan tanah tidak dipergunakan sesuai dengan keadaan atau sifat dan tujuan pemberian haknya. Sedangkan terkait dengan surat peringatan, dilakukan tindakan konkret dalam memberitahukan kepada pemegang hak sekaligus memberikan peringatan tertulis pertama, kedua, dan ketiga masing-masing dalam jangka waktu satu bulan oleh Kanwil BPN, pemegang hak diberikan kesempatan untuk melakukan tindakan konkret.

Tindakankonkretyang dilakukan pemegang hak adalah land clearing dan pengurusan izin-izin. Adanya niat melaksanakan adalah land clearing dan pengurusan izin-izin dan dibuktikan dengan kondisi fisik serta progress terhadap suatu kegiatan kemajuan daripada sebelum ditegur dianggap telah melaksanakan teguran dan tidak perlu surat teguran yang kedua kecuali tidak melaksanakan.

Tidak mungkin pula dalam jangka waktu tiga bulan land clearing dan pengurusan izin-izin dapat diwujudkan mamanfaatkan tanah seluruhnya karena jumlah luasan tanah ratusan hingga ribuan hektar. Hal tersebut berbeda dengan pendapat BPN bahwa land clearing tidak termasuk kategori telah melaksanakan tindakan konkret mamanfaatkan dan mengusahakan tanah.

2. Tujuan penertiban tanah telantar adalah penataan kembali untuk mewujudkan tanah sebagai sumber kesejahteraan rakyat. Pasca pembatalan surat keputusan penetapan tanah telantar oleh pengadilan berimplikasi terhadap:

a. Tidak tercapainya program-program pemerintah seperti redistribusi tanah 9 juta hektar sebagai salah satunya berasal dari HGU habis dan tanah telantar;

b. Tidak terlaksananya pendayagunaan tanah negara diperoleh dari tanah negara bekas tanah telantar sesuai dengan Peraturan Kepala BPN RI Nomor 5 Tahun 2011 yang dialokasikan secara nasional untuk kepentingan masyarakat dan negara melalui:

1) Reforma agraria, program strategis negara, cadangan negara;

2) Tidak terwujudnya tujuan penertiban tanah telantar berdampak pada terhambatnya pencapaian berbagai tujuan program pembangunan, rentannya ketahanan pangan dan ketahanan ekonomi nasional, tertutupnya akses sosial-ekonomi masyarakat khususnya petani pada tanah, serta terusiknya rasa keadilan dan harmoni sosial;

3) Ketimpangan kepemilikan lahan dan konflik agraria semakin tajam. 


\section{SARAN}

Dari kesimpulan yang telah dikemukakan tersebut di atas, dapat diberikan beberapa saran sebagai berikut:

1. Memberikan pengertian-pengertian yang tegas tidak multitafsir mengenai pengertian tanah telantar dan surat peringatan terkait dengan tindakan konkret yang harus dilakukan oleh pemegang hak. Karena pengertian tanah telantar tidak diatur di dalam Peraturan Pemerintah Nomor 11 Tahun 2010 hanya diatur dalam Pasal 1 angka 6 Peraturan Kepala BPN RI Nomor 4 Tahun 2010. Seyogianya dilakukan revisi Peraturan Pemerintah Nomor 11 Tahun 2010.

2. Penertiban dan pendayagunaan tanah telantar sebagai program prioritas BPN harus menetapkan sumber daya manusia yang memahami sengketa tata usaha negara (ahli hukum), karena pada kenyataannya seksi di kantor pertanahan yang menangani sengketa, konflik dan perkara pertanahan mayoritas bukan berlatar belakang ilmu hukum serta secara kuantitas kekurangan sumber daya manusia. Di samping itu tugas-tugas seksi sengketa, konflik dan perkara pertanahan yang ditangani cukup banyak. Karena dalam banyak kasus tanah telantar secara material/fisik benar-benar telantar, bahkan hakim pun mengetahui bahwa tanah tersebut telantar, akan tetapi prosedur formal/administrasi tidak ditaati/tidak sesuai dengan Peraturan Pemerintah Nomor 11 Tahun 2010. Aspek prosedur formal yang tidak ditaati banyak mengakibatkan surat penetapan tanah telantar harus dicabut dan dibatalkan oleh pengadilan tata usaha negara.

\section{DAFTAR ACUAN}

Astina. (1997). Studi tanah telantar di Kotamadya Daerah Tingkat II Padang Provinsi Sumatera Barat. Skripsi. Yogyakarta: Sekolah Tinggi Pertanahan Nasional.

Hadjon, P. M. (2008). Pengantar hukum administrasi Indonesia. Yogyakarta: Gadjah Mada University Press.

Harsono, B. (2007). Hukum agraria Indonesia sejarah pembentukan Undang-Undang Pokok Agraria, isi \& penjelasannya. Edisi Revisi. Jakarta: Djambatan.

Ismail, N. (2012, April). Arah politik hukum pertanahan \& perlindungan kepemilikan tanah masyarakat: Political direction of land law \& protection of people's land ownership. Jurnal Rechtsvinding, 1 (1), 33-51.

Kantor Staf Kepresidenan. (2016, April). Strategi nasional pelaksanaan Reforma Agraria 20162019. Jakarta: Arahan dari Kantor Staf Presiden.

Kementerian Koordinator Bidang Perekonomian. (2017, Mei 17). Rapat Koordinasi Reforma Agraria \& Perhutanan Sosial. Bahan tanyang. Jakarta: Kementerian Koordinator Bidang Perekonomian.

Konsorsium Pembaharuan Agraria (KPA). (2016). Catatan akhir tahun 2016 Konsorsium Pembaruan Agraria: Liberalisasi agraria diperhebat, reforma agraria dibelokkan. Jakarta: Konsorsium Pembaharuan Agraria.

Matutu, M. D. et al. (2004). Mandat, delegasi, atribusi \& implementasinya di Indonesia. Yogyakarta: UII Press.

Muhammad, A. (2004). Hukum \& penelitian hukum. Bandung: PT Citra Aditya Bakti.

Parlindungan, A. P. (1990). Berakhirnya hak-hak atas 
tanah menurut sistem UUPA. Bandung: Mandar Maju.

Sodiki, A. (2013). Politik hukum agraria. Jakarta: Konstitusi Press.

Soetiknjo, I. (1983). Politik agraria nasional; Hubungan manusia dengan tanah yang berdasarkan Pancasila. Yogyakarta: Gadjah Mada University Press.

Suryanto, B. (2017, April 19). Percepatan penyediaan tora \& pelaksanaan reforma agraria (Redistribusi tanah). Bahan tayang. Jakarta: Direktorat Jenderal Penataan Agraria.

Tauhiid, M. (2009). Masalah agraria sebagai masalah penghidupan \& kemakmuran rakyat Indonesia. Yogyakarta: STPN Press.

Vollenhoven, C. V. (1975). De Indonesier en zijngrond. Orang Indonesia \& Tanahnya. Soewargono (Ed.). Jakarta: Pusat Pendidikan Dalam Negeri.

Winoto, J. (2007). Reforma agraria: Mandat politik, konstitusi \& hukum dalam rangka mewujudkan tanah untuk keadilan \& kesejahteraan rakyat. Jakarta: Badan Pertanahan Nasional (BPN). (2010, April 19). Tanah telantar untuk rakyat. Diambil dari wawancara yang dilakukan Majalah GATRA. Jakarta: Badan Pertanahan Nasional (BPN).

Wiradi, G. (2000). Reforma agraria, perjalanan yang belum berakhir. Yogyakarta: Insist Pess, KPA, dan Pustaka Pelajar.

Zakaria, R. Y. et al. (2001). Mensiasati otonomi daerah demi pembaharuan agraria. Bandung: Konsorsium Pembaruan Agraria. 